\title{
Perkembangan Hukum Ekonomi Syariah di Indonesia
}

\author{
Fitrianur Syarif \\ Universitas Andi Djemma \\ Email Correspondensi: fitrianur@unanda.ac.id
}

\section{PLENGS \\ Jurnal Ilmu Hukum LL-DIKTI Wilayah IX Sulawesi}

\author{
Artikel history: \\ Received : $\quad 08$ April, 2019 \\ Revised : $\quad 22$ April, 2019 \\ Accepted : $\quad 2$ Mei, 2019
}

Abstrak Perkembangan ekonomi Islam berlangsung dengan begitu pesat. Hal ini juga didukung oleh sektor hukum, yakni dilandasi dengan keluarnya peraturan perundang- undangan di bidang ekonomi syariah, antara lain adalah keluarnya Undang- undang Nomor 3 Tahun 2006 yang memberikan kewenangan bagi Pengadilan Agama untuk menangani perkara sengketa ekonomi syariah. Selain itu keluarnya Undang-undang Nomor 19 Tahun 2008 tentang Surat Berharga Syariah Negara dan Undang-undang Nomor 21 Tahun 2008 tentang Perbankan Syariah semakin memperkokoh landasan hukum ekonomi syariah di Indonesia. Pada tataran praktis, keberadaan lembaga-lembaga keuangan syariah sekarang ini menunjukkan adanya perkembangan yang semakin pesat. Hal ini sejalan dengan semakin meningkatnya kesadaran sebagian besar umat Islam untuk melaksanakan Islam secara kaffah. Adapun tujuan penelitian dari jurnal ini adalah Untuk Mengetahui perkembangaan Hukum Ekonomi Syariah di Indonesia, dengan metode penelitian penelitian hukum normatif dengan pendekatan konseptual yaitu mencari asas-asas, doktrin-doktrin dan sumber hukum dalam arti filosofis yuridis. Alasan peneliti menggunakan penelitian hukum normatif karena untuk menghasilkan argumentasi, teori atau konsep baru sebagai praktisi dalam menyelesaikan masalah yang dihadapi. Adapun hasil penelitian dan Pembahasan adalah Keberadaan ekonomi syariah di Indoinesia, sesungguhnya suadah mengakar sekalipun keberlakuannya masih bersifat normatif sosiologis.

Abstract. The development of Islamic economics took place so rapidly. This is also supported by the legal sector, which is based on the issuance of laws and regulations in the field of Islamic economics, among others, the issuance of Law Number 3 of 2006 which gives authority to the Religious Courts to handle sharia economic dispute cases. In addition, the issuance of Law Number 19 of 2008 concerning State Sharia Securities and Law Number 21 of 2008 concerning Sharia Banking further strengthens the legal foundation of Islamic economics in Indonesia. At a practical level, the existence of Islamic financial institutions now shows an increasingly rapid development. This is in line with the increasing awareness of the majority 
Keywords:

Hukum Ekonomi;

Ekonomi Syariah;

Ekonomi Islam. of Muslims to implement Islam faithfully. The research objective of this journal is to find out the development of Sharia Economic Law in Indonesia, with normative legal research methods with a conceptual approach that is to seek principles, doctrines and sources of law in a juridical philosophical sense. The reason researchers use normative legal research is to produce new arguments, theories or concepts as practitioners in solving problems they face. The results of the research and discussion are the existence of Islamic economics in Indonesia, in fact it has taken root even though its validity is still normative sociology.

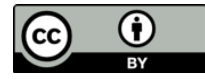

artikel dengan akses terbuka dibawah lisensi CC BY -4.0

\section{PENDAHULUAN}

Sebagai konstitusi ekonomi, Undang-Undang Dasar 1945 juga mengatur bagaimana sistem perekonomian nasional seharusnya disusun dan dikembangkan. Ketentuan utama Undang-Undang Dasar 1945 tentang sistem perekonomian nasional dimuat dalam Bab XIV Pasal 33. Ketentuan tentang sistem perekonomian nasional memang hanya dalam satu pasal yang terdiri dari lima ayat. Namun ketentuan ini harus dielaborasi secara konsisten dengan cita-cita dan dasar negara berdasarkan konsep-konsep dasar yang dikehendaki oleh pendiri bangsa. Selain itu, sistem perekonomian nasional harus dikembangkan terkait dengan hak-hak asasi manusia yang juga mencakup hak-hak ekonomi, serta dengan ketentuan kesejahteraan rakyat. $^{1}$

Secara filosofis, cita-cita hukum ekonomi Indonesia adalah menggagas dan menyiapkan konsep hukum tentang kehidupan ekonomi. Kehidupan ekonomi yang diinginkan adalah kehidupan berbangsa dan bernegara yang rakyatnya memiliki kesejahteraan dan keadilan sosial, sebagaimana yang dicita-citakan Pancasila. Bertolak dari cita-cita tersebut, ke depan hukum ekonomi harus menunjukkan sifat yang akomodatif terhadap: 1) perwujudan masyarakat yang adil dan makmur; 2) keadilan yang proporsional dalam masyarakat; 3) tidak adanya diskriminatif terhadap pelaku ekonomi; 4) persaingan yang tidak sehat. $^{2}$

Cita-cita hukum ekonomi ini searah dengan cita hukum Islam yang tertuang dalam maqōṣid asy-syari'ah dengan berintikan pada membangun dan menciptakan kemaslahatan dunia dan akhirat bagi umat manusia. Cita hukum Islam dalam bidang ekonomi terlihat dalam konsepnya tentang aktivitas ekonomi dipandang sebagai wahana bagi masyarakat untuk membawa kepada, paling tidak pelaksanaan dua ajaran al-Qur'an, yaitu

\footnotetext{
${ }^{1}$ Asshiddiqie, Jimly. (2005). Implikasi Perubahan UUD 1945 Terhadap Pembangunan Hukum Nasional. Jakarta: Konstitusi Press, hlm. 20.

${ }^{2}$ Hartono, Sri Redjeki. (2007). Hukum Ekonomi Indonesia. Malang: Bayumedia Publishing, hlm. 31 .
} 
prinsip saling at- ta'awwun (membantu dan saling bekerja sama antara anggota masyarakat untuk kebaikan) dan prinsip menghindari garar (transaksi bisnis di mana didalamnya terjadi unsur penipuan yang akhirnya merugikan salah satu pihak).

Masuknya unsur Islam (ekonomi syariah) dalam cita hukum ekonomi Indonesia, bukan berarti mengarahkan ekonomi nasional ke arah ideologi ekonomi agama tertentu, tetapi dikarenakan ekonomi syari'ah sudah lama hidup dan berkembang tidak hanya di Indonesia, tetapi juga di dunia. Sistem ekonomi syari'ah adalah salah satu dari sistem-sistem ekonomi lainnya seperti kapitalisme dan sosialisme. Menurut Jimly Asshiddiqie, dalam perspektif konstitusi ekonomi, kita tidak perlu terjebak dalam diskusi mengenai ideologi ekonomi. Ekonomi Syariah keberadaannya mempunyai landasan yang kuat baik secara formal syar'i maupun formal konstitusi. Secara formal syar'i, keberadaan ekonomi Syariah mempunyai landasan dalil yang kuat. Dalam konteks negara, ekonomi Syariah mempunyai landasan konstitusional.

Perkembangan ekonomi Islam atau yang lazim dikenal dengan ekonomi syariah di Indonesia berlangsung dengan begitu pesat. Hal ini juga didukung oleh sektor hukum, yakni dilandasi dengan keluarnya peraturan perundang-undangan di bidang ekonomi syariah, antara lain adalah keluarnya Undang-undang Nomor 3 Tahun 2006 yang memberikan kewenangan bagi Pengadilan Agama untuk menangani perkara sengketa ekonomi syariah. Selain itu keluarnya Undang-undang Nomor 19 Tahun 2008 tentang Surat Berharga Syariah Negara dan Undang-undang Nomor 21 Tahun 2008 tentang Perbankan Syariah semakin memperkokoh landasan hukum ekonomi syariah di Indonesia.

Pada tataran praktis, keberadaan lembaga-lembaga keuangan syariah sekarang ini menunjukkan adanya perkembangan yang semakin pesat. Hal ini sejalan dengan semakin meningkatnya kesadaran sebagian besar umat Islam untuk melaksanakan Islam secara kaffah. Perkembangan ini tentu memberikan harapan baru bagi para pelaku usaha untuk menjalankan bisnis yang tidak hanya berorientasi pada keuntungan materiil semata, tetapi juga sesuai dengan spirit hukum syariah yang menjanjikan pemenuhan kebutuhan batiniyah. ${ }^{3}$

Menurut pandangan Islam bahwa istilah hukum dan syariah merupakan satu kesatuan yang tidak bisa dipisahkan, karena setiap kali mengkaji hukum sejatinya adalah syariah itu sendiri. Pengertian syariah menurut bahasa memiliki beberapa makna, diantaranya berarti jalan yang harus diikuti. Istilah syariah mempunyai akar yang kuat di dalam Al-Quran seperti penjelasan firman Allah: ${ }^{4}$

${ }^{3}$ S., Burhanuddin. (2010). Aspek Hukum Lembaga Keuangan Syariah. Yogyakarta: Graha Ilmu, hlm. 2.

${ }^{4}$ Ibid., hlm. 4. 


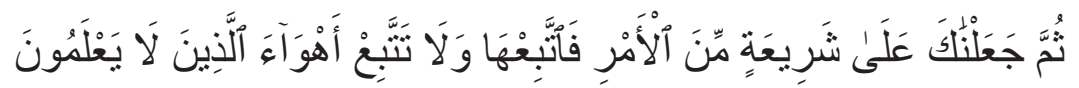

"Kemudian Kami jadikan kamu berada di atas suatu syariat (peraturan) dari urusan (agama) itu, maka ikutilah syariat itu dan janganlah kamu ikuti hawa nafsu orang-orang yang tidak mengetahui." (Q.S. Al- Jatsiyah: 18).

Keterikatan pelaku bisnis pada ketentuan (hukum) syariat yang berlaku, akan memberikan jalan kebenaran sekaligus batasan larangan, sehingga mampu membedakan di antara halal dan haram. Karena itu, pengembangan Hukum Bisnis Syariah merupakan alternatif baru yang bertujuan selain untuk memberikan petunjuk bagaimana mencari keuntungan yang halal bagi pelaku bisnis, juga untuk mencari keridhaan Ilahi.

Perkembangan perbankan syariah diawali dengan munculnya Bank Muamalat Indonesia sekitar tahun 1992 didasarkan pada Undang-undang No. 7 Tahun 1992 sebagai landasan hukum bank kemudian disempurnakan dengan Undang-undang Nomor 10 Tahun 1998 tentang Perubahan atas Undang-undang No. 7 Tahun 1992 tentang Perbankan. Dalam undang-undang tersebut diatur dengan rinci landasan hukum serta jenis-jenis usaha yang dapat dioperasikan dan diimplementasikan oleh bank syariah. Undangundang tersebut juga memberikan arahan bagi bank-bank konvensional untuk membuka cabang syariah atau bahkan mengkonversi diri secara total menjadi bank syariah.

Antusiasme masyarakat terhadap pertumbuhan praktek ekonomi syariah sangat tinggi, terlebih dengan menjamurnya pendirian lembaga keuangan syariah (LKS) baik dalam bentuk Bait at Tamwil, BPRS atau perbankan syariah. Perbankan syari'ah menjadi wadah terpercaya bagi masyarakat yang ingin melakukan investasi dengan sistem bagi hasil secara adil sesuai prinsip syari'ah. Memenuhi rasa keadilan bagi semua pihak dan memberikan maslahat bagi masyarakat luas adalah merupakan prinsip utama bagi bank syari'ah. Oleh karena itu bank syari'ah menerapkan ketentuan dengan menjauhkan diri dari unsur riba dan menjalankan prinsip bagi hasil dan sistem jual beli. ${ }^{5}$

Berdasarkan petunjuk QS. al-Baqarah (2):275 dan QS. al-Nisa (4):29 yang intinya. Allah swt. telah menghalalkan jual beli dan mengharamkan riba serta suruhan untuk menempuh jalan perniagaan dengan suka sama suka, maka setiap transaksi kelembagaan ekonomi syari'ah harus selalu dilandasi atas dasar sistem bagi hasil dan perdagangan atau yang transaksinya didasari oleh adanya pertukaran antara uang dengan barang/jasa.

Masuknya unsur Islam (ekonomi syariah) dalam cita hukum ekonomi Indonesia, bukan berarti mengarahkan ekonomi nasional ke arah ideologi ekonomi agama tertentu, tetapi dikarenakan ekonomi syari'ah sudah lama hidup dan berkembang tidak hanya di Indonesia, tetapi juga di dunia. Sistem

${ }^{5}$ Wirdyaningsih, Perwataatmadja, K., Barlinti, Y. S., \& Dewi, G. (2005). Bank dan Asuransi Islam di Indonesia. Jakarta: Kencana Prenada Media Group, hlm. 17 - 18. 
ekonomi syari'ah adalah salah satu dari sistem- sistem ekonomi lainnya seperti kapitalisme dan sosialisme. Menurut Jimly Asshiddiqie, dalam perspektif konstitusi ekonomi, kita tidak perlu terjebak dalam diskusi mengenai ideologi ekonomi. Ekonomi Syariah keberadaannya mempunyai landasan yang kuat baik secara formal syar'i maupun formal konstitusi. Secara formal syar'i, keberadaan ekonomi Syariah mempunyai landasan dalil yang kuat. Dalam konteks negara, ekonomi Syariah mempunyai landasan konstitusional. Dari uraian singkat diatas penulis akan membahas sebuah tema yang terkait dengan perekonomian syariah khususnya di Indonesia dan akan membahas khususnya mengenai bagaimanakah perkembangan dan keberadaan hukum ekonomi syariah di Indonesia.

\section{METODE}

Penelitian ini merupakan penelitian hukum normatif dengan pendekatan konseptual (conceptual approach) yaitu mencari asasasas, doktrin-doktrin dan sumber hukum dalam arti filosofis yuridis. Alasan peneliti menggunakan penelitian hukum normatif karena untuk menghasilkan argumentasi, teori atau konsep baru sebagai praktisi dalam menyelesaikan masalah yang dihadapi. Kemudian dengan bahan penelitian ini akan dilakukan dengan studi pustaka yang mengkaji bahan hukum Bahan hukum sebagai bahan penelitian diambil dari bahan kepustakaan yang berupa bahan hukum primer, bahan hukum sekunder, bahan hukum tersier dan bahan non hukum sebagai pelengkap pembahasan hasil penelitian ini. Bahan hukum dan bahan non hukum yang diperoleh dalam penelitian ini akan dianalisis secara preskriptif dengan menggunakan metode deduktif yaitu data umum tentang konsepsi hukum baik berupa asas-asas hukum, postulat serta ajaran-ajaran (doktrin) dan pendapat para ahli yang dirangkai secara sistematis sebagai susunan fakta-fakta hukum.

\section{HASIL DAN PEMBAHASAN}

Hukum Islam memiliki akar yang kuat di Indonesia. Hukum Islam ada sejak Islam datang ke Indonesia abad ke-7 M. Ia tumbuh di tengah masyarakat Indonesia berdampingan dengan hukum adat, ${ }^{6}$ bahkan antara keduanya saling memengaruhi. ${ }^{7}$ Selain itu juga hukum Islam kontemporer banyak menyerap konsep yang berasal dari Barat. ${ }^{8}$ Sebelum kekuasaan Hukum Islam dapat menjadi sumber hukum nasional bersama sumber-sumber lainnya yang sudah lama hidup sebagai kesadaran hukum masyarakat Indonesia. Hukum Islam dalam bidang keperdataan, terutama menyangkut hukum keluarga, tetap berlaku bagi umat Islam sebagaimana telah dijadikan politik

${ }^{6}$ Fanani, Muhyar. (2008). Membumikan Hukum Langit: Nasionalisasi Hukum Islam dan Islamisasi Hukum Nasional Pasca Reformasi. Yogyakarta: Tiara Wacana, hlm. 113.

${ }^{7}$ Salah satu bukti pengaruh Islam di Indonesia adalah pengalihan sistem penanggalan tahun Saka yang berdasarkan solar sistem, kepada lunar sistem (penanggalan Hijriah) yang dilakukan oleh Sultan Agung. Adapun Adat yang memengaruhi hukum Islam, tergambar dengan adanya kaidah al-'adat al-muhkamah (adat istiadat berkekuatan hukum). Jazuni. (2005). Legislasi Hukum Islam di Indonesia. Bandung: PT. Citra Aditya Bakti, hlm. 240 - 241.

${ }^{8}$ Coulson, Noel J. (1987). Hukum Islam dalam Perspektif Sejarah (Hamid Ahmad, Trans.). Jakarta: P3M, hlm. 113. 
hukum oleh pemerintah kolonial Belanda sejak tahun 1848 sejauh pemeluk Islam memberlakukan bagi diri mereka. Ini berarti bahwa keberlakuan itu disebabkan oleh kesadaran umat Islam sendiri untuk melaksanakannya, bukan diwajibkan oleh negara. ${ }^{9}$

Hasil penelitian Prof. Mr. Lodewyk Willem Christiaan Van der Berg menunjukkan bahwa hukum Islam berlaku secara total di Indonesia karena seluruh unsur-unsurnya sudah menjadi bagian dari kehidupan hukum masyarakat nusantara. ${ }^{10}$ Pandangan Van der Berg ini melahirkan teori reception in complex ${ }^{11}$ yang merupakan kebalikan dari teori Receptie.

Di Indonesia, hukum Islam adalah hukum yang hidup (living law). Ia berjalan di tengah-tengah masyarakat. Soerjono Soekanto ${ }^{12}$ menyatakan bahwa hukum merupakan konkretisasi dari sistem nilai yang berlaku dalam masyarakat dan suatu keadaan yang dicita-citakan adalah adanya kesesuaian antara hukum dengan sistem nilai tersebut. Dengan demikian, hukum Islam merupakan hukum yang tidak bisa dipisahkan dari masyarakat Indonesia. Ini berbeda dengan hukum positif. Hukum positif lahir karena dilahirkan oleh kekuatan politik yang berkuasa.

Bahwa hukum Islam menjadi sumber hukum nasional bersama hukum Barat dan hukum adat, bukan berarti ia harus menjadi hukum formal dengan bentuk sendiri yang eksklusif, kecuali sifatnya untuk melayani (bukan memberlakukan dengan imperatif) terhadap yang sudah berlaku sebagai kesadaran dalam kehidupan sehari-hari. Di sini sumber hukum harus diartikan sebagai sumber hukum material dalam arti menjadi bahan isi untuk sumber hukum formal. ${ }^{13}$

Menurut Rifyal Ka'bah, hukum Islam dalam konteks hukum nasional adalah hukum yang berciri sendiri. Menurutnya hukum Islam dalam pengertian ini adalah fikih lokal sesuai ijtihad dan kondisi setempat yang diputuskan oleh pembuat undang-undang yang sah dalam suatu negara. Lebih lanjut ia mengatakan:

"Hukum Islam dalam pengertian ini adalah fiqh lokal sesuai ijtihad dan kondisi setempat yang diputuskan oleh pembuat undang-undang yang sah dalam suatu negara. Dengan demikian, hukum Islam dalam praktekyang berlaku dapat berbeda dari satu negara nasional ke negara nasional yang lain seperti perbedaan satu mazhab dengan mazhab yang lain dalam pengertian fiqh tradisional. Sungguhpun demikian, hukum Islam dalam berbagai negara nasional tetap berasal dari sumber yang sama, yaitu

${ }^{9}$ D., Moh. Mahfud M. (2007). Perdebatan Hukum Tata Negara: Pasca Amandemen Konstitusi. Jakarta: LP3ES, hlm. 240.

${ }^{10}$ Sumitro, Warkum. (2005). Perkembangan Hukum Islam di Tengah Kehidupan Sosial Politik di Indonesia. Malang: Bayumedia Publishing, hlm. 35 - 36.

${ }^{11}$ Syahar, Saidus. (1979). Asas-Asas Hukum Islam (Himpunan Kuliah). Bandung: PT. Alumni, hlm. 109.

${ }^{12}$ Amal, Taufik Adnan, \& Panggabean, Samsu Rizal. (2004). Politik Syariat Islam: Dari Indonesia hingga Nigeria. Jakarta: PT. Pustaka Alvabet, hlm. 119.

${ }^{13}$ Ibid. 
syari'at Islam sebagai hukum Illahi yang bertujuan menjaga lima hal seperti tersimpul dalam maqashid asy-syari'ah".14

Sejalan dengan sudah diakuinya kedudukan hukum Islam di Indonesia sebagai salah satu sumber hukum nasional selain hukum adat dan hukum Barat, keperluan untuk selalu mencari dan menggali khazanah hukum Islam dalam rangka memberikan sumbangsih bagi pembentukan hukum nasional adalah sebuah keniscayaan. Lebih-lebih lagi hukum Islam sudah lama mendapat tempat di Indonesia dalam konteks keberlakuannya sudah begitu lama baik secara normatif sosiologis maupun yuridis formal. Menurut Amin Summa, ${ }^{15}$ alasan terpenting dari keberlakuan hukum Islam di Indonesia adalah alasan konstitusi (the reason of constitution) dan alasan sejarah (the reason of history) serta alasan kebutuhan terhadap hukum Islam itu sendiri.

Sekalipun memang pembentukan hukum nasional yang bersumber pada ajaran syari'ah tidak bisa dilepaskan dalam konteks politik hukum nasional, tetapi dalam rangka pengamalan ajaran Islam secara kaffah (sempurna), legislasi hukum Islam diletakkan dalam rangka kebutuhan umat Islam itu sendiri. Oleh sebab itu hukum benar-benar dijalankan secara konsisten, karena dianggap sebagai bentuk pengamalan ajaran Islam yang kaffah sekalipun dalam bentuk peraturan perundang-undangan. Ditambah lagi dengan teori penerimaan otoritas hukum yang prinsipnya menegaskan bahwa hukum Islam menegaskan setiap orang dan siapapun yang telah menyatakan dirinya sebagai seorang muslim, dengan mengucap dua. Politik hukum nasional Indonesia sangat dipengaruhi oleh latar belakang politik dan budaya hukum yang berkembang sejak masa pemerintah kolonial Belanda. Saling pengaruh antara hukum Eropa, Hukum Adat dan hukum Islam dan perkembangan hukum modern dari Anglo Saxon karena perkembangan masyarakat yang semakin global adalah kenyataan hukum yang sahih. Demikian juga pengaruh positivisme hukum nampak lebih kuat, sehingga dapatlah disimpulkan bahwa pengaruh hokum Eropa adalah lebih dominan, walaupun cita-cita hukum yang termuat dalam Pembukaan UUD 1945, seharusnya lebih memperhatikan hukum asli yang tumbuh dan berkembang dari masyarakat Indonesia. kalimat sahadat, ia terikat untuk tunduk kepada hukum dan ajaran Islam. ${ }^{16}$ Karena bagaimanapun juga agar dalam pelaksanaan perundang-undangan yang bertujuan untuk pembaruan itu dapat berjalan sebagaimana mestinya, hendaknya sesuai dengan hukum yang hidup dalam masyarakat. Hal ini sejalan dengan pandangan N.J. Coulson bahwa hukum senantiasa hidup dan berkembang sejalan dengan laju perkembangan suatu masyarakat. ${ }^{17}$

Islam memiliki seperangkat ajaran berupa aqidah, syari'ah dan ibadah. Syari'ah dalam arti khusus disebut juga dengan fikih, terdiri atas beberapa

\footnotetext{
${ }^{14}$ Ka’bah, Rifyal. (1999). Hukum Islam di Indonesia. Jakarta: Universitas Yarsi, hlm. 209.

${ }^{15}$ Suma, Muhammad Amin. (2004). Himpunan Undang-Undang Perdata Islam \& Peraturan Pelaksanaan Lainnya di Negara Hukum Indonesia. Jakarta: PT. Raja Grafindo Persada, hlm. 4.

${ }^{16}$ Anshori, Abdul Ghofur. (2007). Peradilan Agama di Indonesia Pasca UU No. 3 Tahun 2006 (Sejarah, Kedudukan dan Kewenangan). Yogyakarta: UII Press, hlm. 45.

${ }^{17}$ Halim, Abdul. (2010). Peradilan Agama dalam Politik Hukum di Indonesia: Dari Otoriter Konservatif menuju Konfigurasi Demokrasi-Responsif. Jakarta: PT. Raja Grafindo Persada, hlm. 1.
} 
bidang, yaitu bidang ubudiyah (ibadah), munakahat, dan jinayat, dan muamalah. Bidang Muamalah atau diistilah dengan hukum ekonomi syariah membahas tentang: 1) jual beli (al-bai'); 2) gadai (ar-rahnn); 3) kepailitan (taflis); 4) pengampunan (al-hajr); 5) perdamaian (al-șulh); 6) pemindahan utang (al-hiwalah); 7) jaminan utang (ad- daman al-kafalah); 8) perseroan dagang (syarikah); 9) perwakilan (wikalah); 10) titipan (al-wadi'ah); 11) pinjam meminjam (al-ariyah); 12) merampas atau merusak harta orang lain (al-ghasb); 13) hak membeli paksa (syuf'ah); 14) memberi modal dengan bagi untung (qiradh); 15) penggarapan tanah (al-muzaro'ah musaqoh); 16) sewa-menyewa (al-ijaroh), 17) mengupah orang untuk menemukan barang yang hilang (al-ji'alah); 18) membuka tanah baru (ihya al-mawat); dan 19) barang temuan (luqhotah). ${ }^{18}$

Seluruh bidang hukum ekonomi syariah tersebut berdasar prinsip syariah yang mengatur tata niaga, dagang dan tata kelolanya, termasuk mengenai siapa subjek hukum dalam seluruh kegiatan tersebut yang sesuai dengan prinsip syariah. Semuanya didasarkan pada $a l-a q d /$ kontrak. ${ }^{19}$ Normanorma yang bersumber dari hukum Islam di bidang kontrak (perikatan) ini telah lama dipraktikkan dalam masyarakat Islam Indonesia sebagai bagian dari pengamalan ajaran Islam. Namun akibat dari politik penjajah Belanda, norma-norma hukum perikatan Islam ini memudar dan tidak lagi berfungsi dalam praktek formalitas hukum di masyarakat.

Sebelum amandemen Undang-undang No 7 Tahun 1989 tentang Peradilan Agama, penegakkan hukum kontrak bisnis di lembaga-lembaga keuangan syariah tersebut mengacu pada ketentuan Kitab Undangundang Hukum Perdata (KUH Pdt.) yang merupakan terjemahan dari Burgerlijk Wetboek (BW), kitab Undang-undang hukum sipil Belanda yang dikonkordansi keberlakuannya di tanah Jajahan Hindia Belanda sejak tahun 1854 ini, sehingga konsep perikatan dalam Hukum Islam tidak lagi berfungsi dalam praktek formalitas hukum di masyarakat, tetapi yang berlaku adalah KUH Pdt. Secara historis, norma-norma yang bersumber dari hukum Islam di bidang perikatan (transaksi) ini telah lama memudar dari perangkat hukum yang ada akibat politik penjajah yang secara sistematis mengikis keberlakuan hukum Islam di tanah jajahannya, Hindia Belanda. Akibatnya, lembaga perbankan termasuk perbankan syariah maupun di lembagalembaga keuangan lainnya, sangat terbiasa menerapkan ketentuan Buku Ke tiga KHU Pdt. yang merupakan terjemahan dari BW (Burgerlijk Wetboek) tersebut. Sehingga untuk memulai suatu transaksi secara syari'ah tanpa pedoman teknis yang jelas akan sulit sekali dilakukan.

Sejalan dengan bermunculannya lembaga-lembaga keuangan syariah dan dengan adanya undang-undang baru tentang peradilan agama, yaitu Undang-undang No.3 tahun 2006 tentang Perubahan Atas Undang-undang No. 7 tahun 1989 tentang Peradilan Agama, kedudukan hukum perjanjian

${ }^{18}$ Djazuli, H. A. (2006). Ilmu Fiqh: Penggalian, Perkembangan, dan Penerapan Hukum Islam. Jakarta: Kencana Prenada Media Group, hlm. 50.

${ }^{19}$ Hasan, Hasbi. (2010). Kompetensi Peradilan Agama: Dalam Penyelesaian Perkara Ekonomi Syariah. Jakarta: Gramata Publishing, hlm. 108. 
syari'ah atau akad sebagai bagian dari materi hukum ekonomi Syariah secara yuridis formal semakin kuat, yang sebelumnya hanya normatif sosiologis. Lahirnya Undang-Undang No. 3 Tahun 2006 Tentang Peradilan Agama sebagai amandemen terhadap Undang-undang Peradilan Agama yang lama membawa implikasi baru dalam sejarah hukum ekonomi di Indonesia. Selama ini, wewenang untuk menangani perselisihan atau sengketa dalam bidang ekonomi syari'ah diselesaikan di Pengadilan Negeri yang notabenenya belum bisa dianggap sebagai hukum syari'ah.

Ketidakjelasan dan kekosongan hukum positif dalam transaksi bisnis syari'ah menjadi hilang dengan rekomendasi yang diberikan Undang-undang No. 3 Tahun 2006 kepada lembaga Peradilan Agama untuk menyelesaikan kasus sengketa dalam ekonomi syariah, yang meliputi: a. Bank syariah, b. Lembaga keuangan mikro syari'ah, c. Asuransi syari'ah, Reasurasi syari'ah, e. Reksadana syari'ah, f. Obligasi syariah dan surat berharga berjangka menengah syariah, g. Sekuritas syariah, h. Pembiayaan syari'ah, i. Pegadaian syari'ah, j. Dana pensiun lembaga keuangan syari'ah k. Bisnis syari'ah. Ini artinya jangkauan kewenangan mengadili dilingkungan peradilan agama dalam bidang ekonomi syari'ah sudah meliputi keseluruhan bidang ekonomi syari'ah. Sekalipun demikian menurut Cik Basir, ${ }^{20}$ bahwa jenis-jenis ekonomi syari'ah yang tersebut di atas hanya antara lain, yang berarti tidak tertutup kemungkinan adanya kasus-kasus dalam bentuk lain di bidang tersebut selain yang disebutkan itu.

Selain itu juga hukum ekonomi Syariah bertaut dengan hukum perbankan Syariah sebagaimana diatur dalam Undang-Undang No. 21 Tahun 2008 tentang Perbankan Syariah. Dengan adanya undang-undang ini praktek perbankan Syariah semakin kuat, dimana sebelumnya operasionalisasi perbankan Syariah berdasarkan Undang-Undang No. 10 Tahun 1998 tentang Perubahan Undang-Undang No. 7 Tahun 1992 tentang Perbankan. Hukum ekonomi Syariah juga bertaut dengan hukum surat berharga Syariah sebagaimana diatur dalam Undang-Udang No. 19 Tahun 2008 tentang Surat Berharga Syariah, hukum zakat dan wakaf sebagaimana diatur dalam UndangUndang No. 23 Tahun 2011 tentang Pengelolaan Zakat.

Adanya undang-undang yang berkaitan dengan ekonomi syariah menunjukkan bahwa sistem ekonomi Indonesia mulai memberi tempat dan ruang pada ekonomi syariah. Dengan undang-undang tersebut, maka kekosongan hukum dalam bidang ekonomi syariah dapat teratasi, sekalipun belum secara maksimal. Ke depan diharapkan ada revisi terhadap perundang-undangan yang sudah ada menyangkut bidang ekonomi secara umum, sehingga melahirkan duel economic system sebagai payung hukum dalam rangka merealisasikan prinsip-prinsip ekonomi syariah dalam ekonomi Indonesia.

Dalam kaitan dengan hukum Perjanjian di Indonesia, tidak bisa dipungkiri, hukum ini masih merupakan warisan kolonial Belanda, yang sudah seharusnya diperbarui dan disesuaikan dengan karakter atau jadi diri masyarakat Indonesia.

${ }^{20}$ Basir, Cik. (2009). Penyelesaian Sengketa Perbankan Syariah: Di Pengadilan Agama \& Mahkamah Syar'iyah. Jakarta: Kencana Prenada Media Group, hlm. 99. 
Wacana penggantian hukum warisan kolonial dikaitkan dengan hukum apa yang mewarnai pembentukan hukum nasional, melahirkan spektrum pendapat, yaitu sebagian kalangan memandang bahwa hukum Barat peninggalan kolonial itu perlu dipertahankan dengan hanya memperbaruinya dengan berbagai perkembangan baru dalam masyarakat. Pada sisi lain kelompok pelopor hukum adat menghendaki diberlakukan dan diangkatnya hukum adat menjadi hukum nasional Indonesia dan kelompok lain mengusulkan agar syari'at Islam perlu diintrodusir sebagai hukum nasional Indonesia.

Kemudian selain itu, Berbicara tentang ekonomi konstitusi berarti berbicara mengenai perekonomian yang didasarkan atas norma hukum konstitusional yang bersifat mutlak dan tidak boleh dilanggar oleh pembuat dan penentu kebijakan ekonomi yang bersifat aplikatif. Ekonomi Konstitusi adalah perekonomian berdasarkan konstitusi, sedangkan konstitusi ekonomi mengandung norma-norma dasar kebijakan ekonomi. Oleh karenanya, ekonomi konstitusi tidak dapat dipisahkan dari konstitusi ekonomi, dan begitu juga sebaliknya.

Ekonomi syariah sebagai bagian dari aspek ajaran Islam, penerapannya tidak bisa dilepaskan dari kerangka sistem ekonomi Indonesia. Sistem ekonomi Indonesia adalah sistem ekonomi Pancasila yang identik dengan demokrasi ekonomi. Gagasan Demokrasi Ekonomi tercantum dalam UUD 1945 Pasal 33 Ayat (4). Demokrasi ekonomi yang dimaksud adalah demokrasi Pancasila yang menurut Mubyarto ${ }^{21}$ mempunyai ciri-ciri antara lain sebagai berikut: pertama, perekonomian Pancasila digerakkan oleh rangsangan-rangsangan ekonomi, sosial dan yang paling penting adalah moral, kedua, perekonomian Pancasila ada hubungannya dengan Tuhan YME sehinga dalam Pancasila terdapat solidaritas sosial, keempat: perekonomian Pancasila berkaitan dengan persatuan Indonesia, yang berarti nasionalisme menjiwai kebijakan ekonomi, keempat: sistem perekonomian Pancasila tegas dan jelas adanya keseimbangan antara perencanaan sentral (nasional) dengan tekanan pada desentralisasi di dalam pelaksanaan kegiatan ekonomi.

Rumusan yang ada dalam Pasal 33 UUD 1945 menurut Dawam Rahardjo menggambarkan visi tentang sistem ekonomi Indonesia yang dicita-citakan. Ia merupakan gambaran ideal dari suatu sistem alternatif terhadap kapitalisme maupun komunisme. Sistem ekonomi Indonesia berlandaskan pada Pasal 33 UUD 1945 yang dilatarbelakangi oleh jiwa Pembukaan UUD 1945 dan didukung oleh Pasal 18, 23, 27 Ayat (2), dan Pasal 34 UUD 1945. Sistem ekonomi Pancasila adalah sistem ekonomi yang berorientasi atau berwawasan pada sila-sila Pancasila. ${ }^{22}$ Keberadaan Pasal 27 dan pasal 33 UUD 1945 merupakan panduan landasan hokum sistem ekonomi Indonesia. ${ }^{23}$ Menurut Teguh Sulistia, di dalam kedua pasal tersebut

\footnotetext{
${ }^{21}$ Mubyarto. (1998). Sistem dan Moral Ekonomi Indonesia. Jakarta: LP3ES, hlm. 45.

${ }^{22}$ Sukarmi. (2008). Hand Out Bahan Ajar Hukum Ekonomi. Malang: Program Doktor Ilmu Hukum, Universitas Brawijaya.

${ }^{23}$ Saleh, Ismail. (1998). Hubungan Antara Hukum dan Ekonomi. In Sularso Sopater, Bambang Subandrijo, \& Jakob Tobing (Eds.), Perekonomian Indonesia Menyongsong Abad XXI. Jakarta: PT. Pustaka Sinar Harapan, hlm. 201.
} 
tersirat lima asas yang bersentuhan dengan hukum dan ekonomi, yaitu: pertama: asas persamaan di depan hukum; kedua: asas kemanusiaan; ketiga: asas kekeluargaan; keempat: asas manfaat; kelima: asas keseimbangan. ${ }^{24}$

Kelima asas tersebut yang merupakan prinsip ekonomi Indonesia disusun oleh the founding father adalah dalam rangka untuk mampu menuju masyarakat adil dan makmur. Oleh karenanya pembangunan nasional bangsa Indonesia adalah pembangunan manusia seutuhnya dan pembangunan seluruh rakyat Indonesia, dalam arti selain bidang-bidang kebutuhan manusia yang hendak dibangun itu harus seimbang materiil dan sprituil juga pembangunan tersebut harus merata.

Untuk mencapai itu, maka strategi pembangunan harus diarahkan pada pemberdayaan ekonomi rakyat, di mana merupakan pelaksanaan dari demokrasi ekonomi. Arahnya adalah produksi dikerjakan oleh semua untuk semua dan di bawah pimpinan dan kepemilikan anggota-anggota masyarakat. Kemakmuran masyarakat lebih diutamakan ketimbang kemakmuran orang seorang.

Demokrasi ekonomi merupakan kedaulatan rakyat atas perekonomian nasional dan landasan penyelenggaraan perekonomian nasional dengan prinsip kebersamaan, efisiensi berkeadilan, berkelanjutan, berwawasan lingkungan, kemandirian, serta menjaga keseimbangan kemajuan dan kesatuan ekonomi nasional dalam rangka mewujudkan sebesar- besarnya kemakmuran rakyat Indonesia. Istilah demokrasi ekonomi terdapat dalam Pasal 33 ayat (4) UUD 1945. Sebelum amandemen UUD 1945, istilah demokrasi ekonomi terdapat dalam penjelasan UUD 1945. Istilah ini juga terdapat dalam TAP MPRS RI No. XXIII/MPRS/1966 tentang Pembaharuan Kebijakan Ekonomi, Keuangan dan Pembangunan, dan TAP MPR RI No. II/ MPR/19988 tentang Garis-Garis Besar Haluan Negara (GBHN).

Beberapa peraturan perundang-undangan yang terkait di bidang ekonomi seperti Undang-Undang No. 7 Tahun. 1992 tentang Perumahan dan Pemukiman, Undang-Undang No. 7 Tahun 1992 tentang Perbankan dan Undang-Undang No. 10 Tahun 1998 tentang Perubahan atas Undang-Undang No. 7 Tahun 1992 tentang Perbankan, Undang-Undang No. 21 Tahun 2008 tentang Perbankan Syari'ah, Undang-Undang No. 25 Tahun. 1992 tentang Koperasi, Undang-Undang No. 19 Tahun 2003 tentang BUMN, dan UndangUndang No. 20 Tahun 2008 tentang Usaha Mikro, Kecil, dan Menengah, Sejak diamandemennnya Pasal 33 UUD 1945, terjadi pergeseran makna yang terkandung dalam Pasal 33 sebelumnya. Dalam ayat (4) Pasal 33 UUD 1945 (pasca amandemen keempat), kata demokrasi ekonomi memang muncul kembali, tetapi kedudukan dan pengertiannya berubah, karena diletakkannya kata demokrasi ekonomi sebagai salah satu ayat saja dalam Pasal 33 UUD 1945.

${ }^{24}$ Sulistia, Teguh. (2006). Aspek Hukum Usaha Kecil dalam Ekonomi Kerakyatan. Padang: Andalas University Press, hlm. $114-115$. 
Pasal 33 UUD 1945 merupakan cerminan kedaulatan rakyat di bidang ekonomi. Menurut Jimly Asshiddiqie, ${ }^{25}$ Pasal 33 ayat (4) sangat jelas mengembangkan pengertian demokrasi yang tidak hanya mengandung pengertian politik, tetapi juga ekonomi. Artinya, rakyat Indonesia di samping berdaulat di bidang politik juga harus berdaulat di bidang ekonomi. Itulah makna hakiki dari konsep demokrasi ekonomi, yaitu kedaulatan rakyat di bidang ekonomi. Hal ini sejalan juga dengan pandangan Ginanjar Kartasasmita, ${ }^{26}$ bahwa politik Indonesia dengan menganut paham demokrasi harus disertai pula dengan demokrasi ekonomi. Dengan demokrasi ekonomi ingin dijamin bahwa negara ingin mewujudkan keadilan sosial bagi seluruh rakyat Indonesia.

Krisis yang terjadi pada pertengahan tahun 1997 yang menghantam seluruh sendi-sendi perekonomian bangsa telah meluluhlantakan komponen fundamental ekonomi, menyiratkan ada sesuatu yang perlu diperbaiki dalam sistem ekonomi Indonesia, karena sistem ekonomi Indonesia masih memegang prinsip-prinsip kapitalis di mana bunga adalah "nyawa" dari sistem ini yang berakibat pada stagnannya sektor riil. ${ }^{27}$ Krisis ekonomi yang terjadi di Indonesia, termasuk krisis perbankan yang menyebabkan kepercayaan nasabah turun secara drastis, menjadikan pemerintah mulai melirik pada sistem yang berangkat dari sistem ekonomi Syari'ah lewat pengembangan perbankan syari'ah di Indonesia, karena lembaga keuangan syari'ah berperan penting dalam pemulihan perekonomian Indonesia. ${ }^{28}$

Perbankan Syari'ah sebagai sebuah lembaga baru yang kegiatannya berlandaskan pada bangunan sistem ekonomi Syari'ah dapat dikatakan sebagai sebuah pembangunan ide-ide baru dalam sistem ekonomi Indonesia ketika lembaga-lembaga keuangan konvensional tidak mampu membendung krisis ekonomi yang terjadi. Oleh karenanya, lahirnya lembaga-lembaga keuangan yang berbasis pada sistem ekonomi Syari'ah seperti perbankan Syari'ah, menunjukkan bahwa arah dan sasaran politik hukum ekonomi difokuskan pada terciptanya sistem hukum yang mampu memberikan keadilan ekonomi pada masyarakat, mengarahkan perhatian pada ekonomi kerakyatan, terciptanya nasionalisme ekonomi, dan menggunakan tolak ukur pemerataan ekonomi, dan mengukur keberhasilan pembangunan ekonomi. ${ }^{29}$

Penguatan terhadap ekonomi yang berkarakter kerakyatan dengan produk transaksi mudharabah dan transaksi jual beli yang ditawarkan oleh lembaga-lembaga keuangan syari'ah memastikan keterkaitan sektor moneter dan sektor riil. Hal ini sangat berlainan dengan sistem ekonomi konvensional yang perkembangan sektor moneternya tidak terkait dengan sektor riil. Bagaimanapun sektor financial tidak akan pernah lepas kaitan

\footnotetext{
${ }^{25}$ Asshiddiqie, Jimly. (2005). Op. Cit., hlm. 151.

${ }^{26}$ Kartasasmita, Ginanjar. (2007). Mewujudkan Demokrasi Ekonomi dengan Koperasi. In Diskusi Nasional dalam Rangka Peringatan Ulang Tahun Ikatan Cendekiawan Muslim Indonesia (ICMI) yang ke-17. Jakarta: ICMI bekerjasama dengan Bappenas dan GNKL NU.

${ }^{27}$ Bashith, Abdul. (2008). Islam dan Manajemen Koperasi: Prinsip dan Strategi Pengembangan Koperasi di Indonesia. Malang: UIN Malang Press, hlm. 29 - 30.

${ }^{28}$ Sabirin, Syahril. (2003). Perjuangan Keluar dari Krisis. Yogyakarta: BPEF, hlm. 393.

${ }^{29}$ Sulistiyono, Adi. (2007). Reformasi Hukum Ekonomi Indonesia. Surakarta: Lembaga Pengembangan Pendidikan, Universitas Sebelas Maret, hlm. 72.
} 
dengan sektor riil. Jika dalam kenyataannya kedua sektor ini telah mengalami lepas kaitan, maka umat manusia tinggal menunggu kehancuran peradaban.

Konsep hukum ekonomi Syari'ah menjaga keseimbangan sektor riil dan sektor moneter. Bahkan studi-studi tentang sistem ekonomi Syari'ah menggarisbawahi bahwa masalah fiskal merupakan yang utama dan mendapatkan penekanan lebih di banding masalah moneter. Penekanan sistem ekonomi pada fiskal akan lebih mendorong berkembangnya sektor riil dan pemerataan. ${ }^{30}$ Apabila mengaitkan perkembangan konsep serta asasasas hukum yang memberikan dasar atas petunjuk arah dalam pembentukan hukum positif dan kaidah-kaidah hukum tentang bagaimana seharusnya implementasi demokrasi ekonomi dalam sistem ekonomi Syari'ah, ini berarti sudah mengarah pada wacana politik hukum ekonomi. Landasan politik hukum ekonomi Indonesia ada dalam pasal 33 UUD 1945, Pancasila, GBHN dan propenas yang secara luas merupakan penjabaran demokrasi ekonomi.

Bermunculannya lembaga perbankan syariah yang dimulai sejak tahun 1991 dengan lahirnya Bank Muamalat Indonesia merupakan wujud dari penerapan ekonomi syariah di Indonesia.31 Secara Konstitusi keberadaan lembaga perbankan syariah sebagai bagian dari ekonomi syariah diakui. Hal ini dapat dilihat dengan adanya beberapa undang-undang yang berkaitan dengan perbankan/perbankan syariah, seperti Undang-Undang No. 7 Tahun 1992 Tentang Perbankan, Undang-Undang No. 10 Tahun 1998 Tentang Perubahan Undang-Undang No. 7 Tahun 1992 Tentang Perbankan, dan Undang-Undang No. 21 Tahun 2008 Tentang Perbankan Syari'ah.

Selain berupa undang-undang, maka dalam rangka penguatan hukum materil ekonomi syariah, kita telah mempunyai Kompilasi Hukum Ekonomi Syari'ah (KHES) yang berisi 4 (empat) buku, yaitu Buku I tentang Subjek Hukum dan Amwal, Buku II tentang Akad, BukuIII tentang Zakat dan Hibah, dan Buku IV tentang Akuntansi Syari'ah. Keberadaan KHES ini belum dalam bentuk Undang-undang, tetapi berupa Peraturan Mahkamah Agung (PMA) No. 2 Tahun 2008 yang dalam tata urutan perundang-undangan tidak termasuk sebagaimana yang tercantum dalam Undang-undang No. 12 Tahun 2011 tentang Pembentukan Peraturan Perundang-undangan. ${ }^{32}$

${ }^{30}$ Jusmaliani, \& Soekarni, Muhammad (Eds.). (2005). Kebijakan Ekonomi dalam Islam. Yogyakarta: Kreasi Wacana, hlm. 37.

${ }^{31}$ Sahban, \& Aswari, Aan. (2016). Aspek Hukum Preferensi Masyarakat terhadap Akad Mudharabah pada Perbankan Syariah di Kota Makassar. Ishlah: Jurnal Ilmiah Hukum, UMI Makassar, 18(2), hlm. 183.

${ }^{32}$ Undang-Undang No. 12 Tahun 2011 tentang Pembentukan Peraturan PerundangUndangan, Pasal 7 ayat (1) menyebutkan: jenis dan hierarki Perundang-undangan adalah sebagai berikut:

a) Undang-Undang Dasar Negara Republik Indonesia Tahun 1945;

b) Ketetapan Majelis Permusyawaratan Rakyat;

c) Undang-Undang/Peraturan Pemerintah Pengganti Undang-Undang;

d) Peraturan Pemerintah;

e) Peraturan Presiden;

f) Peraturan Daerah Provinsi; dan

g) Peraturan Daerah Kabupaten / Kota. 


\section{KESIMPULAN}

Keberadaan ekonomi syariah di Indonesia, sesungguhnya sudah mengakar sekalipun keberlakuannya masih bersifat normatif sosiologis. Krisis ekonomi yang terjadi di Indonesia tahun 1997, menjadikan pemerintah mulai melirik pada sistem yang berangkat dari sistem ekonomi Syari'ah. Beberapa perangkat hukum untuk memayungi penerapan ekonomi syariah Indonesia sudah relatif banyak, sekalipun belum maksimal. Ke depan perlu upaya yang lebih maksimal dan menyeluruh dalam rangka melengkapi aturan atau regulasi terkait dengan ekonomi syariah, sehingga keberadaan ekonomi syariah menjadi kuat tidak hanya secara normatif sosiologis tetapi juga yuridis formil. Hal yang perlu dilakukan adalah melakukan pembaruan hukum yang merupakan salah satu dimensi dari pembangunan hukum nasional, selain dimensi pemeliharaan dan penciptaan. Yang dimaksud dengan dimensi pembaruan adalah usaha untuk lebih meningkatkan dan menyempurnakan pembangunan hukum nasional yaitu dengan selain pembentukan peraturan perundang-undangan yang baru, juga penyempurnaan peraturan perundang-undangan yang ada sesuai dengan kebutuhan baru di bidang-bidang yang bersangkutan, dalam hal ini bidang ekonomi syariah.

\section{DAFTAR RUJUKAN}

Amal, Taufik Adnan, \& Panggabean, Samsu Rizal. (2004). Politik Syariat Islam: Dari Indonesia hingga Nigeria. Jakarta: PT. Pustaka Alvabet.

Anshori, Abdul Ghofur. (2007). Peradilan Agama di Indonesia Pasca UU No. 3 Tahun 2006 (Sejarah, Kedudukan dan Kewenangan). Yogyakarta: UII Press.

Asshiddiqie, Jimly. (2005). Implikasi Perubahan UUD 1945 Terhadap Pembangunan Hukum Nasional. Jakarta: Konstitusi Press.

Asshiddiqie, Jimly. (2010). Konstitusi Ekonomi. Jakarta: Kompas.

Bashith, Abdul. (2008). Islam dan Manajemen Koperasi: Prinsip dan Strategi Pengembangan Koperasi di Indonesia. Malang: UIN Malang Press.

Basir, Cik. (2009). Penyelesaian Sengketa Perbankan Syariah: Di Pengadilan Agama \& Mahkamah Syar'iyah. Jakarta: Kencana Prenada Media Group.

Bobo, Julius. (2003). Transformasi Ekonomi Rakyat. Jakarta: Cidesindo.

Coulson, Noel J. (1987). Hukum Islam dalam Perspektif Sejarah (Hamid Ahmad, Trans.). Jakarta: P3M.

D., Moh. Mahfud M. (2007). Perdebatan Hukum Tata Negara: Pasca Amandemen Konstitusi. Jakarta: LP3ES.

Djazuli, H. A. (2006). Ilmu Fiqh: Penggalian, Perkembangan, dan Penerapan Hukum Islam. Jakarta: Kencana Prenada Media Group. 
Fanani, Muhyar. (2008). Membumikan Hukum Langit: Nasionalisasi Hukum Islam dan Islamisasi Hukum Nasional Pasca Reformasi. Yogyakarta: Tiara Wacana.

Halim, Abdul. (2010). Peradilan Agama dalam Politik Hukum di Indonesia: Dari Otoriter Konservatif menuju Konfigurasi Demokrasi-Responsif. Jakarta: PT. Raja Grafindo Persada.

Hamidullah, Muhammad. (2003). Fikih Islam \& Hukum Romawi: Refleksi atas Pengaruh Hukum Lama terhadap Hukum Baru (Ali Muhammad \& Rusjdi Ali Muhammad, Trans.). Yogyakarta: Gama Media.

Hartono, Sri Redjeki. (2007). Hukum Ekonomi Indonesia. Malang: Bayumedia Publishing.

Hasan, Hasbi. (2010). Kompetensi Peradilan Agama: Dalam Penyelesaian Perkara Ekonomi Syariah. Jakarta: Gramata Publishing.

Jazuni. (2005). Legislasi Hukum Islam di Indonesia. Bandung: PT. Citra Aditya Bakti.

Jusmaliani, \& Soekarni, Muhammad (Eds.). (2005). Kebijakan Ekonomi dalam Islam. Yogyakarta: Kreasi Wacana.

Ka'bah, Rifyal. (1999). Hukum Islam di Indonesia. Jakarta: Universitas Yarsi.

Kartasasmita, Ginanjar. (2007). Mewujudkan Demokrasi Ekonomi dengan Koperasi. In Diskusi Nasional dalam Rangka Peringatan Ulang Tahun Ikatan Cendekiawan Muslim Indonesia (ICMI) yang ke-17. Jakarta: ICMI bekerjasama dengan Bappenas dan GNKL NU.

Mubyarto. (1998). Sistem dan Moral Ekonomi Indonesia. Jakarta: LP3ES.

Rosyidi, Imron (Ed.) (1997). Agenda Aksi Liberalisasi Ekonomi dan Politik di Indonesia. Yogyakarta: Pusat Pengembangan Manajemen, FE Universitas Islam Indonesia bekerjasama dengan Tiara Wacana.

S., Burhanuddin. (2010). Aspek Hukum Lembaga Keuangan Syariah. Yogyakarta: Graha Ilmu.

Sabirin, Syahril. (2003). Perjuangan Keluar dari Krisis. Yogyakarta: BPEF.

Sahban, \& Aswari, Aan. (2016). Aspek Hukum Preferensi Masyarakat terhadap Akad Mudharabah pada Perbankan Syariah di Kota Makassar. Ishlah: Jurnal Ilmiah Hukum, UMI Makassar, 18(2), 183 - 200.

Saleh, Ismail. (1998). Hubungan Antara Hukum dan Ekonomi. In Sularso Sopater, Bambang Subandrijo, \& Jakob Tobing (Eds.), Perekonomian Indonesia Menyongsong Abad XXI. Jakarta: PT. Pustaka Sinar Harapan.

Sukarmi. (2008). Hand Out Bahan Ajar Hukum Ekonomi. Malang: Program Doktor Ilmu Hukum, Universitas Brawijaya. 
Pleno Jure, Vol. 9 (2), Fitrianur Syarif, Perkembangan Hukum Ekonomi ...

Sulistia, Teguh. (2006). Aspek Hukum Usaha Kecil dalam Ekonomi Kerakyatan. Padang: Andalas University Press.

Sulistiyono, Adi. (2007). Reformasi Hukum Ekonomi Indonesia. Surakarta: Lembaga Pengembangan Pendidikan, Universitas Sebelas Maret.

Suma, Muhammad Amin. (2004). Himpunan Undang-Undang Perdata Islam \& Peraturan Pelaksanaan Lainnya di Negara Hukum Indonesia. Jakarta: PT. Raja Grafindo Persada.

Sumitro, Warkum. (2005). Perkembangan Hukum Islam di Tengah Kehidupan Sosial Politik di Indonesia. Malang: Bayumedia Publishing.

Syahar, Saidus. (1979). Asas-Asas Hukum Islam (Himpunan Kuliah). Bandung: PT. Alumni.

Wirdyaningsih, Perwataatmadja, K., Barlinti, Y. S., \& Dewi, G. (2005). Bank dan Asuransi Islam di Indonesia. Jakarta: Kencana Prenada Media Group. 